\title{
High-protein meals may benefit fat oxidation and energy expenditure in individuals with higher body fat.
}

Citation for published version (APA):

Batterham, M., Cavanagh, R., Jenkins, A., Tapsell, L., Plasqui, G., \& Clifton, P. M. (2008). High-protein meals may benefit fat oxidation and energy expenditure in individuals with higher body fat. Nutrition \& Dietetics, 65(4), 246-252. https://doi.org/10.1111/j.1747-0080.2008.00311.x

Document status and date:

Published: 01/01/2008

DOI:

10.1111/j.1747-0080.2008.00311.x

Document Version:

Publisher's PDF, also known as Version of record

Document license:

Taverne

Please check the document version of this publication:

- A submitted manuscript is the version of the article upon submission and before peer-review. There can be important differences between the submitted version and the official published version of record.

People interested in the research are advised to contact the author for the final version of the publication, or visit the DOI to the publisher's website.

- The final author version and the galley proof are versions of the publication after peer review.

- The final published version features the final layout of the paper including the volume, issue and page numbers.

Link to publication

\footnotetext{
General rights rights.

- You may freely distribute the URL identifying the publication in the public portal. please follow below link for the End User Agreement:

www.umlib.nl/taverne-license

Take down policy

If you believe that this document breaches copyright please contact us at:

repository@maastrichtuniversity.nl

providing details and we will investigate your claim.
}

Copyright and moral rights for the publications made accessible in the public portal are retained by the authors and/or other copyright owners and it is a condition of accessing publications that users recognise and abide by the legal requirements associated with these

- Users may download and print one copy of any publication from the public portal for the purpose of private study or research.

- You may not further distribute the material or use it for any profit-making activity or commercial gain

If the publication is distributed under the terms of Article $25 \mathrm{fa}$ of the Dutch Copyright Act, indicated by the "Taverne" license above, 


\title{
ORIGINAL RESEARCH
}

\section{High-protein meals may benefit fat oxidation and energy expenditure in individuals with higher body fat}

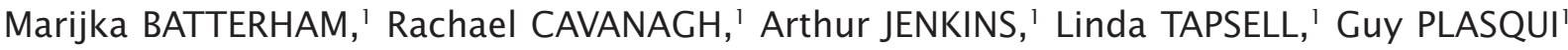 \\ and Peter CLIFTON² \\ 'Smart Foods Centre, School of Health Sciences, and ${ }^{2}$ CSIRO Human Nutrition, Adelaide, South Australia, \\ Australia
}

\begin{abstract}
Aim: Fat oxidation is impaired in obesity. The aim of the present study was to determine if fat oxidation, seen in a high-protein meal response, was influenced by body composition.

Methods: Subjects were provided with control (14\% protein, glycaemic index, GI 65), high-protein high-GI (33\% protein, GI 74) and high-protein low-GI (35\% protein, GI 45) meals. Substrate oxidation and energy expenditure were measured in room calorimeters over eight hours in 18 subjects. Results were compared using a repeated-measures ANOVA with a customised post-hoc analysis (to compare the protein diets averaged vs control and to compare the lowand high-Gl diets) and covariates in a linear model of the form: $y=\alpha+\beta_{1} \times$ fat-free mass $(\mathrm{kg})+\beta_{2} \times \mathrm{log}_{\mathrm{e}}$ fat mass $(\mathrm{kg})$. Results: The full model found significant meal effects on fat oxidation $(0.21 \pm 0.21 \mathrm{kcal} / \mathrm{minute}$ high-protein high-GI, $0.34 \pm 0.11 \mathrm{kcal} /$ minute high-protein low-Gl, $0.55 \pm 0.2 \mathrm{kcal} /$ minute control, $F=3.50, P=0.007)$. The effect on energy expenditure $(1.67 \pm 0.07 \mathrm{kcal} /$ minute high-protein high-Gl, $1.61 \pm 0.08 \mathrm{kcal} / \mathrm{minute}$ high-protein low-Gl, $1.67 \pm 0.08 \mathrm{kcal} /$ minute control) approached significance $(F=2.45, P=0.070)$. Post-hoc analysis revealed a protein effect $(P=0.004$ for fat oxidation and $P=0.030$ for energy expenditure). Significant interactions indicated that meal response was influenced by body composition. The high-protein meals eliminated the negative relationship between body fat and fat oxidation $\left(\alpha=-4.7, \beta_{2}=2.23, P<0.01\right)$ and between body fat and energy expenditure, which were evident in the control meal $\left(\alpha=-1.5, \beta_{2}=0.63, P<0.05\right)$. No effect of GI was evident.
\end{abstract}

Conclusion: High-protein intakes may ameliorate an obesity-induced decline in fat oxidation.

Key words: body composition, energy expenditure, obesity, substrate utilisation.

\section{INTRODUCTION}

There is some evidence that a diet high in protein may promote weight loss. $^{1-3}$ Higher dietary protein intakes ( $>25 \%$ of energy) have been reported to have a higher thermogenic effect. Studies investigating the effects of highprotein diets on thermogenesis have generally included subjects homogeneous in body composition. ${ }^{4-12}$ Where both normal and obese subjects have been recruited results have

M. Batterham, PhD, APD, Post Doctoral Fellow

R. Cavanagh, MND, APD, Dietitian

A. Jenkins, PhD, Associate Professor

L. Tapsell, PhD, FDAA, Professor

G. Plasqui, PhD, Associate Lecturer

P. Clifton, PhD, Professor

Correspondence: M. Batterham, School of Health Sciences,

University of Wollongong, Northfields Ave, Wollongong, NSW, 2522.

Email:marijka@uow.edu.au

Accepted August 2008 either been divided into the two body composition groups $^{13}$ or presented in a format that did not adjust for body composition differences in the study population. ${ }^{14,15}$ More recently, Labayen and colleagues investigated differences in energy expenditure and substrate utilisation in obese and lean women consuming high-protein and control meals as a liquid supplement. ${ }^{16}$ They reported no significant differences in thermogenesis between the protein and control meals when body composition was included as a covariate. This result suggests that body composition (including both the fat and fat-free mass) must be adjusted for in analyses where samples are heterogeneous in body composition. Fat oxidation was reported to be improved in the obese subjects, following the high-protein supplement in that study.

Fat oxidation has been shown to be impaired in obese and post-obese subjects, ${ }^{17,18}$ so dietary strategies that improve fat oxidation may be particularly beneficial. As insulin resistance has been shown to be negatively associated with 
fasting fat oxidation and positively associated with postprandial fat oxidation in obese subjects, ${ }^{19}$ dietary strategies that displace fat in the diet may be particularly beneficial for treatment of metabolic syndrome.

In the context of a meal, the aim of the present study was to test the effects of a realistic increase in dietary protein on acute energy expenditure and substrate oxidation in a group of healthy individuals varying in body composition. As lower-glycaemic index (GI) foods have been reported to increase fat oxidation,$^{20}$ the protein-enriched meals used in the present study contained either predominantly low-GI or predominantly high-GI sources of carbohydrate. Thus, a secondary aim of this research was to determine if incorporating low-GI foods in a high-protein diet would enhance any thermogenic effects.

\section{METHODS}

\section{Recruitment and ethics}

Healthy adult subjects were recruited through advertisement. Exclusion criteria were signs or symptoms of chronic disease, or taking any medication known to affect metabolic rate. All subjects gave written informed consent to participate in the study and the study was approved by the University of Wollongong/Illawarra Area Health Service Ethics Committee. All measurements were conducted at the University of Wollongong room calorimetry facility and associated nutrition laboratories.

\section{Experimental protocol}

The study was an acute randomised cross-over design. Subjects attended a pre-study screening visit to familiarise the subjects with the calorimeter facility and to ascertain that they were willing to consume the study foods. Subjects were instructed to consume their usual diet and avoid strenuous activity for at least 24 hours before the study.

Subjects then attended three study visits one month apart for the women and at least one week apart for the men. Subjects arrived fasting on each occasion, were asked to empty their bladder and then had their body composition and weight assessed before entering the chamber for an eighthour stay. Gas measurements commenced between 8:00 and 9:00 a.m. and ended eight hours later. Breakfast was provided 30 minutes after entering the chamber and lunch was served 210 minutes after the breakfast meal. Subjects engaged in sedentary activity (using the computer, watching television) between meal times. Subjects kept an activity diary in the chamber, so they were able to replicate their activity on each study visit. Urine was collected during the stay.

\section{Test meals}

The energy values and macronutrient composition of the meals used were calculated using the Foodworks nutrient analysis software program (version 3, 2002; Xyris Software, Brisbane, Australia) using the Australian nutrient database
AUSNUT. The meals provided and the macronutrient breakdown are outlined in Appendix I. The meals differed in the amount of protein and the carbohydrate types provided. The caloric intake of each of the diet was designed to be similar in energy, fat calories and type and the amount of calcium provided.

\section{Body composition}

Weight was measured using electronic scales (Tanita TBF622, Tanita Corporation of Japan, Tokyo, Japan) and body composition was estimated using a tetrapolar bioelectrical impedance analyser (Bodystat 1500, Bodystat Ltd, Douglas, IM, USA). We have previously validated this analyser for use in our laboratory by comparison with dual-energy X-ray absorptiometry. ${ }^{21}$ The intra-class correlation for absolute agreement of this instrument for the four measurements (screening and the three study visits) in the 18 subjects who participated in the study was 0.966 , indicating good reliability.

\section{Indirect calorimetry}

Oxygen consumption and carbon dioxide production were measured in the whole room calorimeter facility at the University of Wollongong. The facility consists of two separate air-tight, ventilated and air-conditioned chambers furnished like small hotel rooms $(3 \mathrm{~m} \times 2.1 \mathrm{~m})$, each with a bed, desk, chair, hand basin, television and video/DVD player, computer, telephone and toilet. Each chamber has three windows, each with interior privacy blinds, looking outside the building (ocean view), into the surrounding laboratory and into the adjacent chamber. Access to the subjects for the investigators is provided by airlocks through which food and other materials can be passed. Temperature was maintained at $24^{\circ} \mathrm{C}$ and ventilated with fresh air measured by a solidstate gas sample drying system (Peltier dryer, Maastricht Instruments, Netherlands). Oxygen concentration was measured using a paramagnetic oxygen analyser (Sable System Inc., PA-IB, Las Vegas, NV, USA) and carbon dioxide was measured using an infrared analyser (Sable System Inc., Las Vegas, NV, USA). Oxygen and carbon dioxide measurements were corrected to standard temperature, pressure and dry from fresh air temperature, water vapour pressure and barometric pressure measurements. Data were collected by means of a data acquisition system connected to a computer to store and analyse the data. The differential oxygen and carbon dioxide analysers were manually calibrated against fresh air for zero readings and against a span gas and nitrogen each study day. Chamber air was sampled every two minutes. Rates of oxygen consumption and carbon dioxide production were calculated from the measured inflow and outflow according to Schoffelen et al. ${ }^{22}$ with minor modifications. Specifically, measurement noise in the raw data was reduced by smoothing with cubic spline functions; smoothed data accounted for $97.3 \pm 2.2 \%$ (SD) and $99.96 \pm 0.02 \%$ of the variance in outlet oxygen and carbon dioxide, respectively. Urinary nitrogen was estimated from 
measured urinary urea. Rates of energy expenditure $e^{23}$ and fuel utilisation ${ }^{24}$ were calculated. Data were expressed per subject (e.g. kcal/minute). The within-subject coefficients of variation for repeated 24-hour measurements in four subjects, of $2.5 \%, 1.7 \%, 2.5 \%$ for oxygen, carbon dioxide and energy expenditure, respectively, compare favourably with similar facilities.

\section{DATA ANALYSIS}

\section{Models}

Measures of rates of gas exchange and derived rates of fuel were analysed against measures of body composition as covariates in models of the form:

\section{$y=\alpha+\beta_{1} \times$ fat-free mass $(\mathrm{kg})+\beta_{2} \times \log _{\mathrm{e}}$ fat mass $(\mathrm{kg})$.}

These models assume that metabolic activity is a linear function of fat-free mass, ${ }^{25}$ with an additional independent effect of body fat mass. Absolute fat mass rather than percentage body fat was used, because the fixed absolute nutrient loads delivered across subjects were assumed to be competing with the absolute amounts of endogenous stores represented by the fat mass and because body fat percentage contains information related to the fat-free mass that is already explicit in the models. Fat mass was $\log _{e}(\mathrm{Ln})$-transformed under the assumption that any effects would be saturable. It was assumed in these analyses that any effects of sex are a consequence of sex difference in body size and composition. ${ }^{26}$

\section{Statistical analysis}

Analyses were performed using the JMP package (version 4.0.1, SAS Institute Inc.). All metabolic data were analysed initially by repeated-measures MANOVA (simple or nested repeats) in the models described above.

The period between subject entry and the presentation of breakfast (approximately 30 minutes) was used to estimate fasting (basal) rates of fuel metabolism. In preliminary analyses (simple repeated-measures MANOVA), there were no differences between estimates obtained on the three study days and the fasting data were therefore averaged across the three studies in all subsequent analyses. These averaged data were analysed using the model described above.

In preliminary analyses, data obtained from the presentation of breakfast to the exit from the chamber were blocked into two meal-related periods of 150 minutes each and two inter-meal periods. These data were then analysed in a nested repeated-measures MANOVA (four repeats in time within study and three repeats in diet between studies). This analysis found no significant effects of time within study, so all data were then averaged within each study to provide estimates of fuel metabolism during the fed period in subsequent analyses. These averaged data were analysed by repeated-measures MANOVA (repeats in diet) using the models described above, with planned contrasts between control and both high-protein diets (protein effect) and between the two high-protein diets (GI effect). As no significant GI effects were detected on any variable (see Table 1),

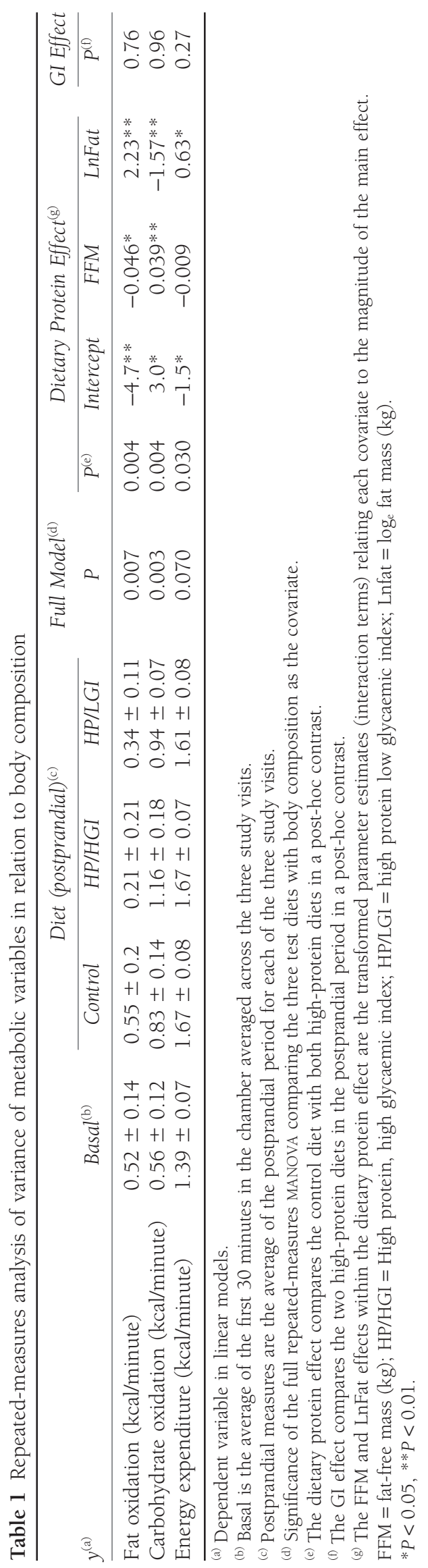

(C) 2008 The Authors

Journal compilation (C) 2008 Dietitians Association of Australia 
Table 2 Baseline characteristics of the study participants

\begin{tabular}{lcc}
\hline & Male $(n=5)$ & Female $(n=13)$ \\
\hline Weight $(\mathrm{kg})$ & $98.7 \pm 9.4(86.3-111.6)$ & $68.8 \pm 9.7(58.9-77.1)$ \\
BMI $\left(\mathrm{kg} / \mathrm{m}^{2}\right)$ & $30.2 \pm 3.9(25.0-36.0)$ & $24.9 \pm 2.8(21.4-29.5)$ \\
Body fat $(\%)$ & $29.5 \pm 5.1(16.0-41.9)$ & $32.3 \pm 6.1(24.2-38.1)$ \\
Fat-free mass $(\mathrm{kg})$ & $69.0 \pm 4.5(62.5-74.3)$ & $46.6 \pm 4.2(41.0-55.3)$ \\
\hline
\end{tabular}

Values are mean \pm standard deviation (range).

$\mathrm{BMI}=$ body mass index.

the protein effects are illustrated using multiple linear regression analysis of data averaged across the two high-protein studies compared with a similar analysis of the control diet data.

\section{RESULTS}

Of the 68 people who responded to study advertisements, 23 were eligible and agreed to participate and 18 of these completed the three study visits. The five subjects not completing the three visits cited personal reasons and scheduling incompatibilities as their reasons for discontinuing the study. The mean age of the participants was $39.8 \pm 12.9$ years, six subjects were classified as having a normal body mass index, eight subjects were overweight and four were obese. There was also considerable variation in body fat and fat-free mass (Table 2)

Table 1 shows the results of the repeated-measures MANOVA analysis. Significant overall effects were observed for fat and carbohydrate oxidation in the repeated-measures MANOVA with the model for energy expenditure approaching significance (Table 1). As with any repeated-measures MANOVA involving covariates, the interpretation of the model must consider the interaction between the dependent variables (in this case dietary type) and the covariates (in this case fat-free mass and Ln fat mass (LnFat)). In the post-hoc analysis of the planned contrasts for the GI and protein effects (also shown in Table 1), the dietary protein effect was assessed from a comparison of the control diet with both high-protein diets and the GI effect from a comparison of the two high-protein diets. The fat-free mass and LnFat effects within the dietary protein effect were M-transformed parameter estimates (interaction terms) relating each covariate to the magnitude of the main effect. No significant GI effects were detected and further analysis of the GI effect was not conducted.

Strong interactions between LnFat and dietary protein on substrate oxidation measures and energy expenditure were evident. Interactions between fat-free mass values and those for dietary protein and substrate oxidation (but not energy expenditure) were significant. To investigate these interactions further, scatterplots, including the least squares regression line, are presented in Figure 1 for energy expenditure (Figure la,b), fat oxidation (Figure $1 \mathrm{c}, \mathrm{d}$ ) and carbohydrate oxidation (Figure le,f) for LnFat and fat-free mass, respectively. The effects of the high-protein diet identified (seen in Table 1) thus reflect the presence of a substantial positive relationship between fat-free mass and fat oxidation. It also reflects a negative relationship between fat mass and fat oxidation, and between fat mass and energy expenditure, which are not evident in the high protein-fed state.

\section{DISCUSSION}

The expected ubiquitous elevations in fat oxidation and energy expenditure on a high-protein diet were not found in the present study, possibly because most previous work ${ }^{4-7,9-12}$ has been done without substantial variation in body composition. While in our case an effect may have been masked by variation in body composition, the consistent failure of previous studies to investigate body composition effects is a significant limitation, given clear evidence that fat oxidation is impaired in obesity and in those who were previously obese. ${ }^{17,18}$ Our approach is more informative than previous attempts that have divided the study sample into two body composition groups ${ }^{13}$ or presented in a format that did not adjust for body composition differences in the study sample. ${ }^{14,15}$

Our results present a clear relationship between body composition and the effect of dietary protein on substrate oxidation, suggesting that a high-protein intake may prevent the obesity-induced decrease in fat oxidation. The higherprotein intake resulted in preferential fat utilisation in subjects with higher body fat and a sparing of fat utilisation in those with lower body fat. A more recent study comparing differences in energy expenditure and substrate oxidation in obese and lean women consuming liquid high-protein and control meals found a significant increase in fat oxidation in the obese subjects after the high-protein meal and no significant differences in thermogenesis between the protein and control meals when body composition was included as a covariate. ${ }^{16}$ Although we did not find similar effects for fat oxidation, our results are consistent with these findings for thermogenesis. Our design differed in that we have investigated the relationship between dietary protein and substrate oxidation and between dietary protein and energy expenditure within the group as a whole. Our results demonstrate both the previously acknowledged negative linear relationship between fat oxidation and body fat on the control diet and the novel finding of a normalising of this relationship on the high-protein meals. Similarly, the negative relationship between energy expenditure and body fat was also normalised on the high-protein meals. 

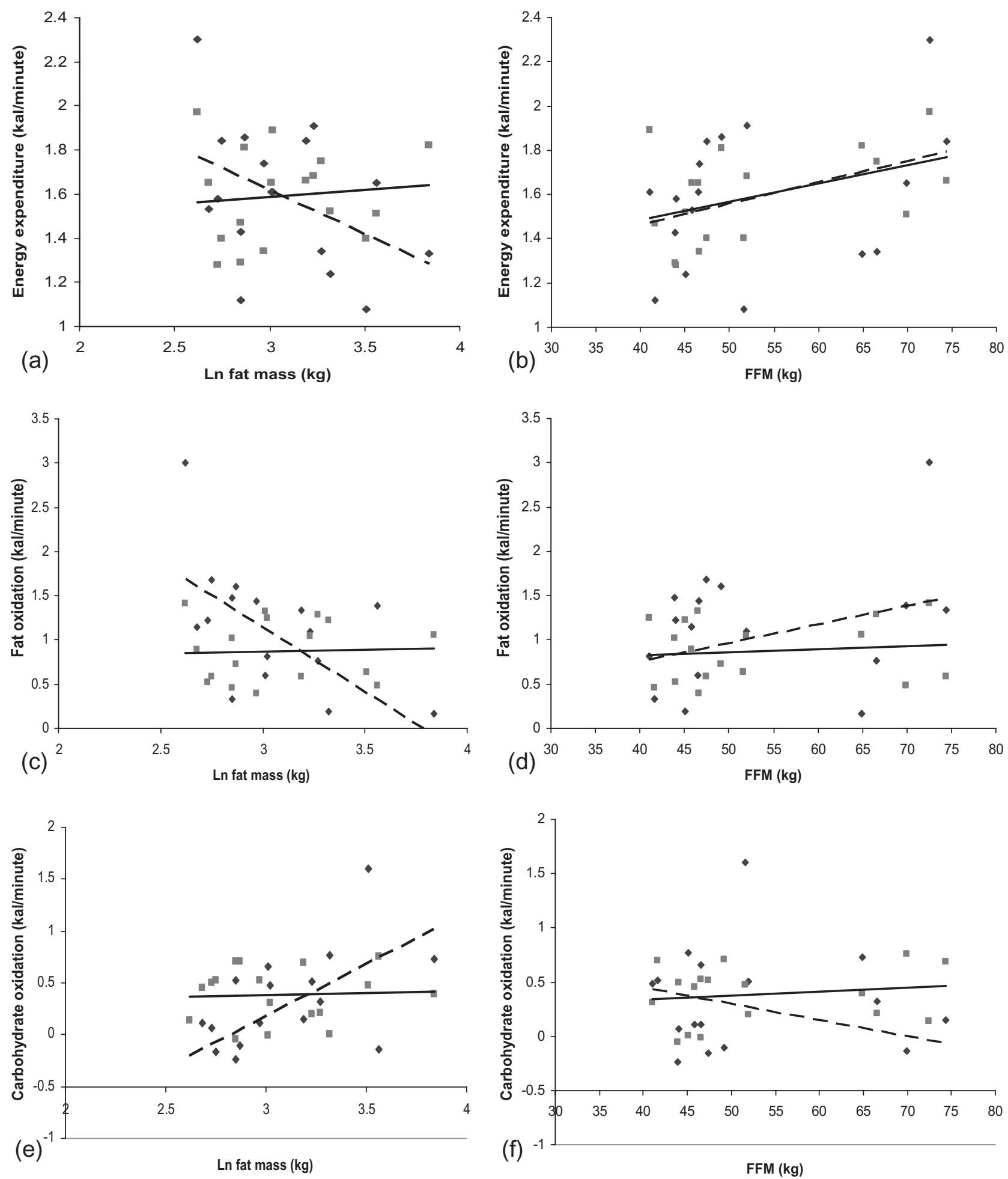

Figure 1 Scatterplots showing the relationship between energy expenditure, fat and carbohydrate oxidation and body composition. $(\boldsymbol{)})$ Values for subjects on the control meals, ( $\boldsymbol{\square})$ values for the average of the values for the subjects on the high-protein high-glycaemic index and the high-protein low-glycaemic index meals. Least squares regression slopes are shown for the control (- - ) and high-protein (_ $)$ meals. FFM, fat-free mass (kg), Ln fat mass, $\log _{e}$ fat mass (kg). 
Lower-GI foods have been reported to increase fat oxidation; ${ }^{20}$ however, most research showing a favourable effect of a lower-GI meal has been conducted in young healthy populations before exercise. ${ }^{27,28}$ Meal-based studies do not show differences in fat oxidation or energy expenditure when GI is varied in an overweight population. ${ }^{29}$ Our results are in agreement with the lack of an acute effect of GI on energy expenditure and substrate utilisation in a meal-based approach in a non-exercising population.

Limitations to our research include the use of bioelectrical impedance to assess body composition. The use of this method has been questioned particularly in those with abdominal obesity, as a greater proportion of total body water (on which the impedance estimate is based) will be in the trunk area, which contributes significantly less to total body impedance. In this case, the total body impedance will be high compared with the amount of body water. ${ }^{30,31} \mathrm{Nev}$ ertheless, we have validated measurements against dualenergy X-ray absoprtiometry in a similar study population ${ }^{21}$ (with body fat ranging from 13\% to 51\%) and therefore have reasonable confidence in our results. Adaptability to substrate delivery is another consideration. There is evidence that the obese person may adapt more slowly to high-fat diets and have a reduced ability to use fat. ${ }^{32}$ Although fat intake was matched in the control and high-protein diets, the results of our study suggest that future research might investigate replacing some of the fat in the meal with protein to determine possible further effects. Finally, insulin resistance might be an issue and this was not assessed in our study. Recent research using high-fat loads suggests that insulin resistance is positively associated with postprandial fat oxidation independent of body composition. ${ }^{19}$ Further research might consider the impact of insulin resistance on possible effects of high-protein diets in altering fat oxidation.

\section{CONCLUSION}

The results of the present study suggest that high-protein meals may have particularly beneficial effects on energy expenditure and fat oxidation in overweight subjects. The present study also demonstrates the need to incorporate body composition, including both fat and fat-free components, in modelling the response of energy expenditure and substrate utilisation to variations in the macronutrient content of meals. This adjustment may be particularly important in the study populations where body composition is known to vary.

\section{ACKNOWLEDGEMENT}

The study was funded by the National Centre of Excellence in Functional Foods.

\section{REFERENCES}

1 Eisenstein J, Roberts SB, Dallal G, Saltzman E. High-protein weight-loss diets: are they safe and do they work? A review of the experimental and epidemiologic data. Nutr Rev 2002; 60: 189-200.

2 Skov AR, Toubro S, Ronn B, Holm L, Astrup A. Randomized trial on protein versus carbohydrate in ad libitum fat reduced diet for the treatment of obesity. Int J Obes Relat Metab Disord 1999; 23: 528-36.

3 St Jeor ST, Howard BV, Prewitt TE, Bovee V, Bazzarre T, Eckel RH. Dietary protein and weight reduction: a statement for healthcare professionals from the Nutrition Committee of the Council on Nutrition, Physical Activity and Metabolism of the American Heart Association. Circulation 2001; 104: 186974.

4 Crovetti R, Porrini M, Santangelo A, Testolin G. The influence of thermic effect of food on satiety. Eur J Clin Nutr 1998; 52: 482-8.

5 Dauncey MJ, Bingham SA. Dependence of 24 hours energy expenditure in man on the composition of the nutrient intake. Br J Nutr 1983; 50: 1-13.

6 Johnston CS, Day CS, Swan PD. Postprandial thermogenesis is increased $100 \%$ on a high-protein, low-fat diet versus a highcarbohydrate, low-fat diet in healthy, young women. J Am Coll Nutr 2002; 21: 55-61.

7 Karst H, Steiniger J, Noack R, Steglich HD. Diet-induced thermogenesis in man: thermic effects of single proteins, carbohydrates and fats depending on their energy amount. Ann Nutr Metab 1984; 28: 245-52.

8 Luscombe ND, Clifton PM, Noakes M, Parker B, Wittert G. Effects of energy-restricted diets containing increased protein on weight loss, resting energy expenditure and the thermic effect of feeding in type 2 diabetes. Diabetes Care 2002; 25: 652-7.

9 Mikkelsen PB, Toubro S, Astrup A. Effect of fat-reduced diets on 24-hour energy expenditure: comparisons between animal protein, vegetable protein and carbohydrate. Am J Clin Nutr 2000; 72: 1135-41.

10 Schutz Y, Bray G, Margen S. Postprandial thermogenesis at rest and during exercise in elderly men ingesting two levels of protein. J Am Coll Nutr 1987; 6: 497-506.

11 Westerterp KR, Wilson SA, Rolland V. Diet induced thermogenesis measured over $24 \mathrm{~h}$ in a respiration chamber: effect of diet composition. Int J Obes Relat Metab Disord 1999; 23: 28792.

12 Luscombe ND, Clifton PM, Noakes M, Farnsworth E, Wittert G. Effect of a high protein, energy restricted diet on weight loss and energy expenditure after weight stabilisation in hyperinsulinemic subjects. Int J Obes 2003; 27: 582-90.

13 Steiniger J, Karst H, Noack R, Steglich HD. Diet-induced thermogenesis in man: thermic effects of single protein and carbohydrate test meals in lean and obese subjects. Ann Nutr Metab 1987; 31: 117-25.

14 Nair KS, Halliday D, Garrow JS. Thermic response to isoenergetic protein, carbohydrate or fat meals in lean and obese subjects. Clin Sci (Lond) 1983; 65: 307-12.

15 Zed C, James WP. Dietary thermogenesis in obesity. Response to carbohydrate and protein meals: the effect of beta-adrenergic blockade and semistarvation. Int J Obes 1986; 10: 391-405.

16 Labayen I, Diez N, Parra D, Gonzalez A, Martinez JA. Basal and postprandial substrate oxidation rates in obese women receiving two test meals with different protein contents. Clin Nutr 2004; 23: $571-8$.

17 Zurlo F, Lillioja S, Esposito-Del Puente A et al. Low ratio of fat to carbohydrate oxidation as predictor of weight gain: study of 24-hour RQ. Am J Physiol 1990; 259: E650-57. 
18 Astrup A, Buemann B, Christensen NJ, Toubro S. Failure to increase lipid oxidation in response to increasing dietary fat content in formerly obese women. Am J Physiol 1994; 266: E592-9.

19 Blaak EE, Hul G, Verdich C et al. Fat oxidation before and after a high fat load in the obese insulin-resistant state. J Clin Endocrinol Metab 2006; 91: 1462-9.

20 Brand-Miller JC, Holt SH, Pawlak DB, McMillan J. Glycemic index and obesity. Am J Clin Nutr 2002; 76: 281S-5S.

21 Batterham M, Tapsell LC, Jenkins AB. A comparison of bioelectrical impedance and near infra-red interactance with dual energy $\mathrm{x}$-ray absorptiometry for assessing body composition in healthy adults. Nutr Diet 2002; 59: 120-26.

22 Schoffelen P, Westerterp KR, Saris WH, ten Hoor F. A dualrespiration chamber system with automated calibration. J Appl Physiol 1997; 83: 2064-72.

23 Weir JB. New methods for calculating metabolic rate with special reference to protein metabolism. J Physiol 1949; 109: $1-9$.

24 Jequier E, Acheson K, Schutz Y. Assessment of energy expenditure and fuel utilization in man. Annu Rev Nutr 1987; 7: 187208.

25 Ravussin E, Lillioja S, Anderson TE, Christin L, Bogardus C. Determinants of 24-hour energy expenditure in man. J Clin Invest 1986; 78: 1568-78.
26 Poehlman ET, Toth MJ. Mathematical ratios lead to spurious conclusions regarding age- and sex-related difference in resting metabolic rate. Am J Clin Nutr 1995; 61: 4825.

27 Stevenson EJ, Williams C, Marsh LE, Phillips B, Nute ML. Influence of high-carbohydrate mixed meals with different glycemic indexes on substrate utilization during subsequent exercise in women. Am J Clin Nutr 2006; 84: 354-60.

28 Wu C-L, Nicholas C, Williams C, Took A, Hardy L. The influence of high-carbohydrate meals with different glycaemic indices on substrate utilisation during subsequent exercise. Br J Nutr 2003; 90: 1049-56.

29 Diaz EO, Galgani JE, Aguirre CA, Atwater IJ, Burrows R. Effect of glycemic index on whole-body substrate oxidation in obese women. Int J Obes 2005; 29: 108-14.

30 Swan PD, McConnell KE. Anthropometry and bioelectrical impedance inconsistently predicts fatness in women with regional adiposity. Med Sci Sports Exerc 1999; 31: 1068-75.

31 Deurenberg P. Limitation of the bioelectrical impedance method for the assessment of body fat in severe obesity. Am J Clin Nutr 1996; 64: S449-S52.

32 Thomas CD, Peters JC, Reed GW, Abumrad NN, Sun M, Hill JO. Nutrient balance and energy expenditure during ad libitum feeding of high-fat and high-carbohydrate diets in humans. Am J Clin Nutr 1992; 55: 934-42.

\section{APPENDIX I}

Macronutrient composition ${ }^{1}$ and menu for the test meals provided in the study

\begin{tabular}{|c|c|c|c|}
\hline & Control & High-protein low-GI & High-protein high-GI \\
\hline Energy (kJ) & 4064 & 4034 & 4240 \\
\hline Protein (g) & 34 & 83 & 83 \\
\hline Fat $(\mathrm{g})$ & 32 & 33 & 35 \\
\hline Carbohydrate (g) & 139 & 84 & 90 \\
\hline Fibre (g) & 8 & 8 & 5 \\
\hline$\%$ Protein & 14 & 35 & 33 \\
\hline$\%$ Fat & 29 & 30 & 31 \\
\hline$\%$ Carbohydrate & 58 & 35 & 36 \\
\hline MUFA (\%) & 50 & 51 & 53 \\
\hline PUFA (\%) & 18 & 14 & 10 \\
\hline SFA (\%) & 32 & 35 & 38 \\
\hline Calcium (mg) & 788 & 736 & 788 \\
\hline Total glycaemic load breakfast & 50 & 6 & 26 \\
\hline GI of breakfast meal & 65 & 49 & 73 \\
\hline Total glycaemic load lunch & 39 & 21 & 30 \\
\hline GI of lunch meal & 65 & 41 & 74 \\
\hline \multirow[t]{8}{*}{ Menu } & Breakfast & Breakfast & Breakfast \\
\hline & White decaffeinated coffee & White decaffeinated coffee & $\begin{array}{l}\text { White decaffeinated coffee } \\
\text { Rice cereal, sugar and milk }\end{array}$ \\
\hline & Cornflakes, sugar and milk & Cheese and tomato omelette & Spanish omelette and bacon \\
\hline & Bread, margarine and jam & $\begin{array}{l}\text { Bread with margarine and } \\
\text { bacon }\end{array}$ & \\
\hline & Lunch & Lunch & Lunch \\
\hline & $\begin{array}{l}\text { Cheese sandwich with salad } \\
\text { vegetables and pesto }\end{array}$ & $\begin{array}{l}\text { Open sandwich with beef, } \\
\text { chutney and salad } \\
\text { vegetables }\end{array}$ & $\begin{array}{l}\text { Open sandwich with beef, } \\
\text { cheese, salad vegetables and } \\
\text { a vinaigrette dressing }\end{array}$ \\
\hline & Rice pudding & Low-fat fruit yoghurt & White decaffeinated coffee \\
\hline & White decaffeinated coffee & White decaffeinated coffee & \\
\hline
\end{tabular}

\footnotetext{
${ }^{1}$ The energy values and macronutrient composition of the meals used were calculated using the Foodworks nutrient analysis software
} program (version 3, 2002; Xyris Software, Brisbane, Australia) using the Australian nutrient database AUSNUT. 